\title{
Exploring Scientific Literacy of Chemistry Education Pre-Service Teachers Through Socio-Scientific Issues Approach
}

\author{
Jajang Muhariyansah ${ }^{1 *}$, Atik Rahmawati ${ }^{1}$, Anita Fibonacci ${ }^{1}$ and Fajar Naqsyahbandi ${ }^{1}$ \\ ${ }^{1}$ Chemistry Education, Faculty of Science and Technology, UIN Walisongo, Jl. Dr. Hamka, \\ Tambakaji, Kec. Ngaliyan, Kota Semarang, 50185, Indonesia \\ *Email:jajangmuhariyansyah@gmail.com
}

Received: 28 November 2021; Accepted: 27 December 2021; Published: 31 December 2021

\begin{abstract}
Scientific literacy is an ability that must be had by pre-service teachers. This research aimed to find out the scientific literacy's ability of pre-service teachers in chemistry education. This research was descriptive with quantitative approach. Participants were taken by simple random sampling techniques, the participants are chemistry education students. The data source comes from scientific literacy tests with socio-scientific issues and open-ended question description tests. The validity of the data was tested using a data triangulation technique, in which researchers compare data obtained through test instruments and interview results. The results of the data analysis showed the scientific literacy of chemistry education students was dominant in the nominal and functional categories with a percentage of $33.2 \%$ and $24.2 \%$, conceptual and multidimensional categories $13.7 \% ; 4.4 \%$; and $24.5 \%$ of students did not give answers the tests.
\end{abstract}

Keywords: environmental pollution, scientific literacy, socio-scientific issues

DOI: http://doi.org/10.15575/jtk.v6i2.15145

\section{Introduction}

The rapid development of information technology in the $21^{\text {st }}$-century will fundamentally change how we live, work, even connect with others around us, called the industrial revolution 4.0 (Tjandrawinata, 2016; Prasetyo \& Sutopo, 2018). Rubin(2004) stated that today's rapid flow of information is analogous to the term information explosion. Information easily spreads so quickly that students as the nation's next generation must make mental preparations in anticipation of the negative impact of the rapid flow of this information.

Information technology has a positive and negative impact on society; ease of access to information to interact socially online is one of the positive impacts of information technology (Rodin, 2014). The negative impact is the issue of moral ethics and social science issues that cause the rise of hoax news (false news) received by the general public (Jamaluddin, 2019). For example, in 2018, a video went viral of a citizen doing a small experiment by burning a sachet of coffee that allegedly contained gunpowder because it can cause fire when burned, even though the news is not scientifically true (Pramurdiarja, 2018). Based on scientific studies conducted, coffee used for experiments is creamer sugar coffee with compositions in sugar, vegetable creamers, and instant ground coffee. The coffee product is in the form of light powder; this causes the coffee powder to be flammable; BPOM explained that food products with a carbon chain (bonds between carbon atoms), low water content, fragile and porous could burn if ignited by fire (Prasasti, 2018).

Learners need to be able to sort out the correct information and absorb information 
J Muhariyansah, A Rahmawati, A Fibonacci \& F Naqsyahbandi

wisely and with critical thinking called scientific literacy skills (Jamaluddin, 2019). Udompong \& Wongwanich research (2014) shows that students with good scientific literacy skills have a level of sensitivity, high care, and responsiveness to socio-scientific issues that develop in society and contribute to providing solutions in solving problems related to socio-scientific issues.

Learners in understanding socio-scientific issues are often correlated with scientific literacy skills. Scientific literacy is an ability that every individual must have (Sartika et al., 2018) because scientific literacy is used to apply scientific knowledge and skills, identify problems faced, and draw conclusions based on empirical evidence and data. The purpose of overall scientific literacy is that the community is prepared to be a sensitive society and responsible for its problems (Sadler, 2011).

Individuals with high scientific literacy skills can implement their science skills to solve socio-scientific issues that develop in their daily lives (Noviana \& Julianto, 2017). Socioscientific issues are a problem that occurs and is based on scientific concepts related to the social sphere because of their controversial nature (Zeidler et al., 2009). Nuangchalerm (2010) research shows that socio-scientific issues discussions are closely related to scientific literacy. Environmental pollution material is one of the materials taught in environmental chemistry courses. The selection of environmental pollution material is based because this material is closely related to socio-scientific issues. Based on the observations made by researchers, it was produced that environmental pollution material in the UIN Walisongo chemical education study program has been taught in the context of socio-scientific issues.

Facts show the lack of an optimal science education process that emphasizes the meaning of learning so that it also has an impact on the low scientific literacy of learners (Pantiwati \& Husamah, 2014). This is in line with the International Programme for International Student Assessment (PISA)
Exploring Scientific Literacy of Chemistry Education Pre-Service Teachers Through SocioScientific Issues Approach

survey by the Organization for Economic Cooperation and Development (OECD), which shows the scientific literacy ability of Indonesian learners is in a low category. The average score of scientific literacy achievement was ranked $70^{\text {th }}$ out of 79 participating countries with a score of 396, while the average PISA score of OECD participants for scientific literacy was 489 (Schleicher, 2018). Improving the scientific literacy of learners is important to be improved so as not to lag behind neighboring countries. If not guided by skilled and professional educators, learners will not achieve optimal performance. Therefore, efforts to foster the culture of scientific literacy of learners, of course, must be supported by the good scientific literacy that an educator has (Sartika et al., 2018).

Chemistry education program as an institution that scores aspiring chemical educators in high school is considered very important to have a qualified scientific literacy ability. Chemistry Education, Faculty of Science and Technology, UIN Walisongo has a vision of a superior and competitive chemistry education study program with the insight of education for sustainable development through research-based unity of science at the Asian level in 2038. Based on this vision, analyzing the scientific literacy skills of chemistry education students is important, because chemistry education students are prospective educators, where educators will be key in sustainable education (Leicht et al., 2018).

Holbrook \& Rannikmae (2009) revealed that by improving scientific literacy through science education, learners can develop the ability to utilize effective evidence-based science knowledge and skills in solving problems closely related to social science issues with responsible decisions. Socioscientific issues are controversial social issues with scientific concepts and procedural links (Sadler, 2004). Learning with socio-scientific issues is the main thing in shaping the character of learners who have scientific literacy to familiarize themselves in acting with science, filter information, and provide 
J Muhariyansah, A Rahmawati, A Fibonacci \& F Naqsyahbandi

decisions related to controversial sociotechnical issues (Zeidler \& Nichols, 2009).

Fives et al.(2014) said that scientific literacy is the ability to understand scientific processes and engage meaningfully with the scientific information available in everyday life. Meaningful learning is understood as connecting new information with prior knowledge in relevant ways. The importance of scientific literacy for pre-service teacher students as an inseparable part of education. The need for research on the analysis of scientific literacy skills of chemical education students on socio-scientific issues understanding. This research was conducted as the basis for the development process of further research related to the scientific literacy of chemical education students.

\section{Research Method}

Type of this research is descriptive with a quantitative approach. This research was conducted from October 2019 to June 2020. The research was conducted at the Chemistry Education, Faculty of Science and Technology UIN Walisongo Semarang (Campus II), Jl. Prof. Dr. Hamka, KM 2 Ngaliyan Semarang.

This research focuses on finding out the scientific literacy ability of pre-service chemistry teachers of UIN Walisongo Semarang on environmental pollution materials with socio-scientific issues and describe the level of scientific literacy of preservice chemistry teachers with the category of scientific literacy (Shwartz et al., 2006). The instrument indicators of this test are as follows by scientific literacy categories:

\subsection{Nominal Scientific Literacy}

Nominal scientific literacy able to recognize the concept of science. The indicators are (1) students recognize concepts related to science, but their level of understanding clearly indicates they do not understand the concept; (2) indicated misconceptions.
Exploring Scientific Literacy of Chemistry Education Pre-Service Teachers Through SocioScientific Issues Approach

\subsection{Functional Scientific Literacy}

Functional scientific literacy able to define some basic concepts of science. The indicators are (1) students are able to explain the basic concepts of science in the text; (2) students can explain the concept of science correctly, but the level of understanding of the concept of science is limited (low).

\subsection{Conceptual Scientific Literacy}

Conceptual scientific literacy able to use their understanding of the concept of science to explain phenomena. The indicators are (1) students understand the basic conceptual schemes of a discipline and connect them with their general understanding of science; (2) have an understanding of the investigation, by looking for the correct information from text, graphs or tables.

\subsection{Multidimensional Scientific Literacy}

Multidimensional scientific literacy able to associate basic concepts with daily life, understand how science, society and technology are interconnected and influence each other. The indicators are (1) students are able to combine understanding of science beyond the concepts of scientific research disciplines and procedures covering philosophical, historical, social, science and technology dimensions; (2) develop some understanding and appreciation of science and technology regarding its relationship with daily life, more specifically students began to make connections in the discipline between science, technology and social science issues (Shwartz et al., 2006; Soobard \& Rannikmae 2011).

Data collection techniques used in this research are by participatory observation, observation in the form of direct observation and researchers have participated in environmental chemistry lectures so that the observation results obtained will be more complete and sharp (Sugiyono, 2017), 
J Muhariyansah, A Rahmawati, A Fibonacci \& F Naqsyahbandi

interviews are conversations with specific intentions (Moleong, 2017). Interviews are intended to obtain valid and more in-depth information and strengthen the results of data analysis obtained from the techniques of scientific literacy test instruments, the entire interview process is conducted through the WhatsApp application and recorded with the permission of each participant.

The data validity test in this study used triangulation examination techniques, in which researchers compared data obtained through test instruments with interviews to obtain true and valid data from students (Moleong, 2017). The data analysis technique used in this study is constant comparative, in data analysis while still comparing one data with another data followed by constantly comparing categories with other categories. Analysis of student answer patterns on scientific literacy test instruments categorized according to each student's ability. According to experts, there are 4 categories of scientific literacy ability: nominal, functional, conceptual, and multidimensional (Bybee, 1997; Shwartz et al., 2006).

Scientific literacy test with socio-scientific issues in the form of open-ended questions about four environmental pollution phenomena presented in writing. This is based on Shwartz et al (2006) on scientific literacy assessment. The phenomenon includes the phenomenon of west canal flood water pollution, presented through news articles that represent indicators of accuracy explaining environmental pollution of the waters both examples, sources, types of pollutants, and efforts to control it. The acid rain phenomenon was chosen because the acid rain phenomenon is one of the social science problems caused by human activities (Cahyono, 2007a; Cahyono, 2007b) this phenomenon represents an indicator of accuracy in explaining the pollution of the air environment both examples, sources, types of pollutants, and efforts to control it.
Exploring Scientific Literacy of Chemistry Education Pre-Service Teachers Through SocioScientific Issues Approach

The next phenomenon is the phenomenon of forest and land fires presented in the form of news articles and bar diagrams that represent indicators of accuracy explaining soil environmental pollution both examples, sources, types of pollutants, and efforts to control them. Depleting the ozone layer becomes the last phenomenon presented in the form of news articles to represent the sharp indicators of analyzing the causative factors and the impact of problems (environmental impacts, social, economic, health) of the global environment in the perspective of science and islam.

Each phenomenon consists of four question points representing nominal categories, functional, conceptual, and multidimensional (Odja \& Payu, 2014). Students can be said to have scientific literacy skills in nominal categories are students who have been able to recognize the concept of science but are indicated to have a misconception.

The ability of scientific literacy students in functional categories have indications that students have a good understanding of the concept of science but limited knowledge, students who already have a qualified science knowledge by developing some understanding of the basic conceptual scheme of a discipline and connecting it with general understanding categorized into conceptual categories, while students who are able to combine the understanding of science by going beyond the concept of disciplines and procedures of scientific investigation that includes philosophical dimensions, history, social, science and technology are categorized into multidimensional categories (Shwartz et al., 2006; Soobard \& Rannikmae, 2011).

Students' scientific literacy skills are categorized into multidimentional categories when students are able to associate basic concepts of science with daily life, understand how science, society and technology are interconnected and influence each other (Soobard \& Rannikmae, 2011; Odja \& payu 2014). 
J Muhariyansah, A Rahmawati, A Fibonacci \& F Naqsyahbandi

\section{Result and Discussion}

The results of interviews with prospective chemistry teachers showed that students were able to write $\mathrm{NH}_{3}$ structures by following octet rules, but the student could not mention the bond on one $\mathrm{NH}_{3}$ molecule, which are covalent bonds and indicated to be misconceptions, because the student stated that in one molecule of $\mathrm{NH}_{3}$ there is a hydrogen bond. Hydrogen bonds are bonds between molecules between hydrogen atoms and atoms that have high negativity in this case fluorine, oxygen and nitrogen atoms (Chang, 2005).

All scientific literacy test questions have been empirically tested for validity and reliability in 22 students of the class of 2016 and have been validated by expert validators, which is
Exploring Scientific Literacy of Chemistry Education Pre-Service Teachers Through SocioScientific Issues Approach

lecturers of chemistry education, Walisongo State Islamic University Semarang. The following are presented examples of answers from students categorized into functional categories as shown in Figure 1.

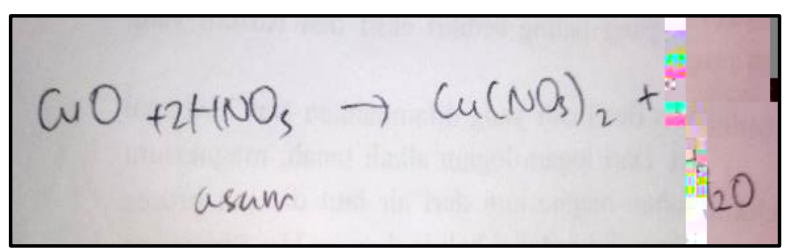

Figure 1. Examples of Student Answers on Test Number 2 Point b

Based on the results of the socio-scientific issues scientific literacy ability test tested, the average percentage of scientific literacy skills category of chemistry education students is presented in Figure 2.

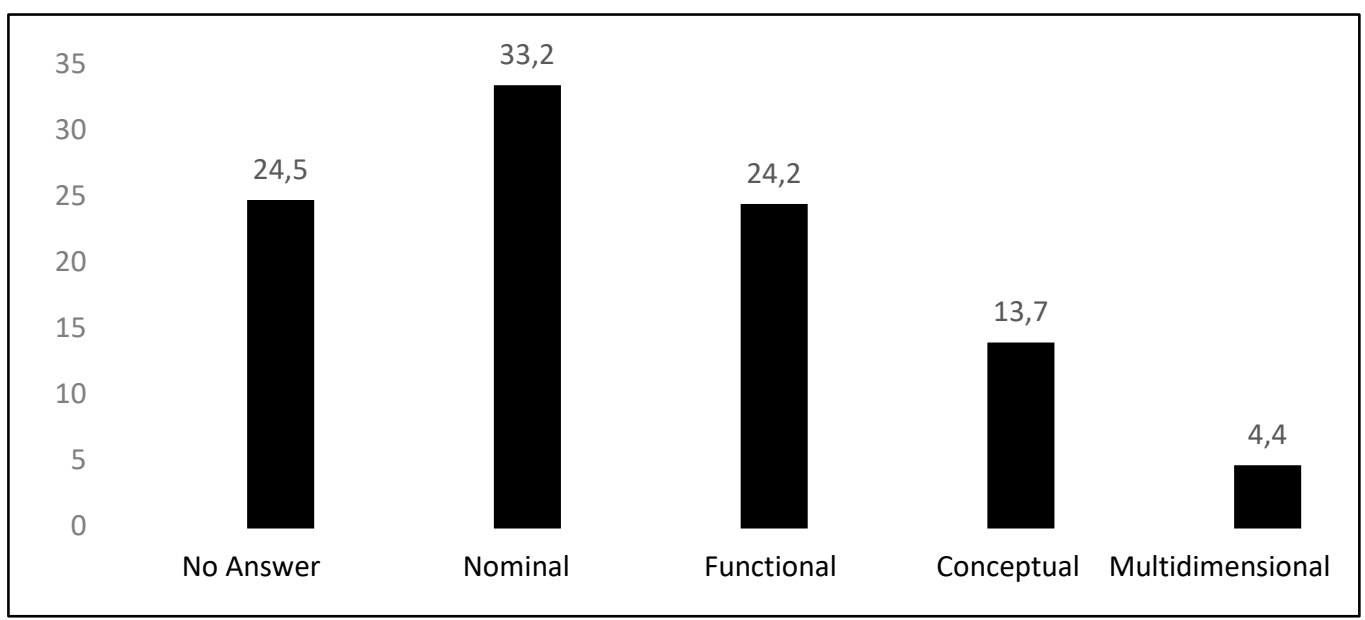

Figure 2. Graph of The Average Percentage of Scientific Literacy Ability of Chemistry Education Students

Based on Figure 2, it is known that the lowest average percentage of scientific literacy category is $4.4 \%$ in multidimensional category. While the highest average percentage is in the nominal category of $33.2 \%$. The highest percentage of students who have the ability to scientific literacy nominal category is found in the accuracy indicators explaining water environmental pollution both examples, sources, types of pollutants, and efforts to control it (13.6\%).
The ability of functional category scientific literacy dominates in all indicators, but the highest percentage is found in accuracy indicators explaining soil environmental pollution both examples, sources, types of pollutants, and efforts to control it (8.2\%). The conceptual category has an average student percentage of $13.7 \%$. Details of the percentage of students' scientific literacy skills for all categories in each question indicator can be seen in Figure 3. 


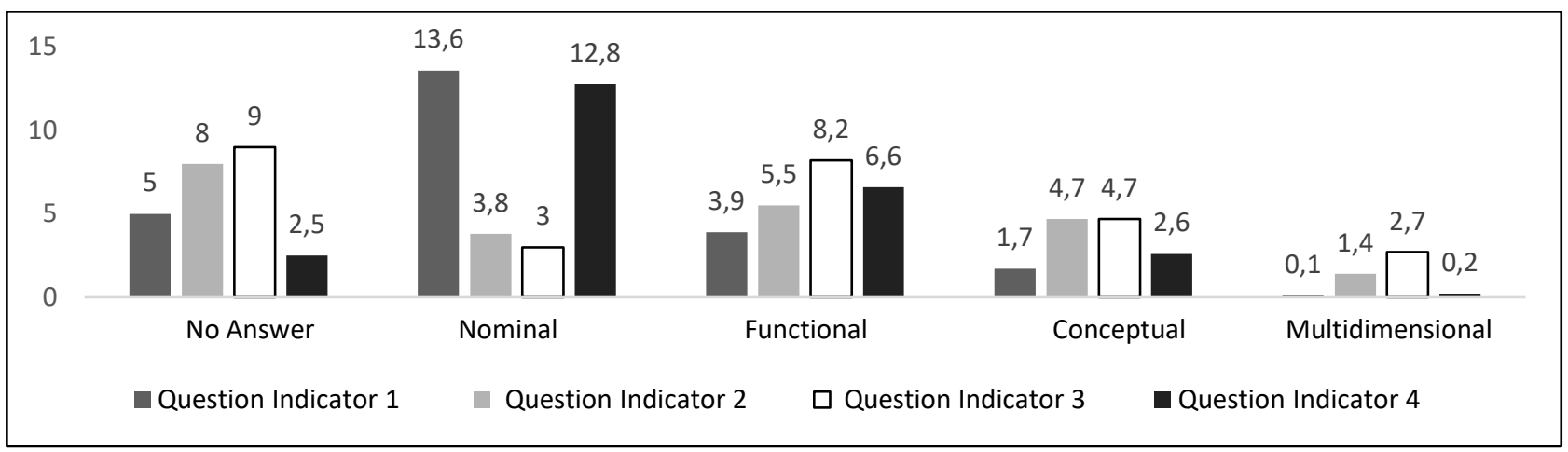

Figure 3. Distribution of Percentage of Students' Scientific Literacy Ability Each Problem Indicator

The highest percentage of student scientific literacy category in nominal category is in question number 1 as much as $13.6 \%$, for functional category the highest percentage on question number 3 is $8.2 \%$, for conceptual categories on questions 3 and 4 get the same percentage of $4.7 \%$, while as many as $24.5 \%$ of students do not answer questions in all indicators of the question. This shows the inability of students to give scientific answers, in line with research conducted by Wijayanti et al (2015) more than 10\% of students are not able to answer scientific literacy test questions and students are only able to achieve 2 categories, which are nominal and functional. The following categories of scientific literacy skills are presented based on analysis of question answers and interview results.

\subsection{Various Categories of Student Scientific literacy Skills in Explaining Aquatic Environmental Pollution}

Overall, students were only able to reach the nominal category with a fairly high percentage and only $0.5 \%$ of students were able to reach the multidimensional category, but as many as $21.8 \%$ of students were unable to answer questions as shown in Figure 4.

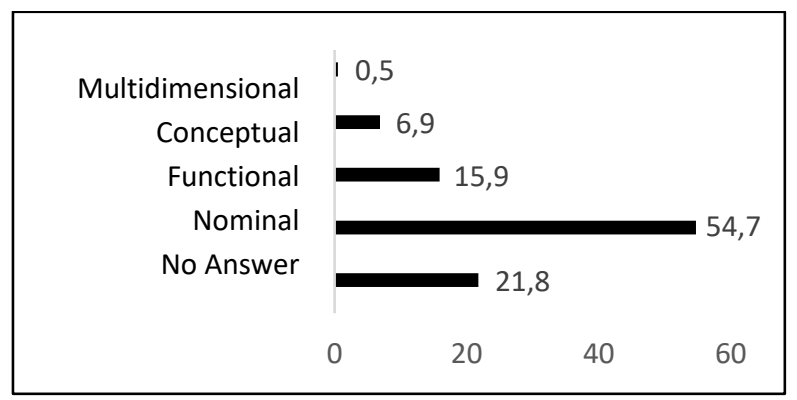

Figure 4. Percentage Distribution of Student Answers on Problem Number 1
Based on the results of test analysis and interviews, it is known that students are hesitant about the answer, this indicates that students have not been able to recognize the basic concepts of science and indicated misconceptions so that it can fall into the nominal category $(54.7 \%)$. In line with this, Wijayanti et al (2015) reported that scientific literacy owned by primary school teacher education students is in the nominal category of $50 \%$. Based on the results of test analysis and interviews, it is known that students are hesitant about the answer, this indicates that students have not been able to recognize the basic concepts of science and indicated misconceptions so that it can fall into the nominal category (54.7\%). In line with this, Wijayanti et al (2015) reported that scientific literacy owned by primary school teacher education students is in the nominal category of $50 \%$.

Multidimensional category on the question: give at least three recommendations for handling solid waste ammonia, only able to achieve as much as $0.5 \%$ only. This is because the student only gives examples of ammonia solid waste management techniques but the student themselves does not understand how the concept of the technique they recommended, based on the test results and interviews, the student stated that he did not know the advantages and disadvantages of the technique they recommended and admitted there were errors when answering the question given. Only a small number of students are able to achieve the multidimensional category, this is reinforced from the results of interviews to students who 
J Muhariyansah, A Rahmawati, A Fibonacci \& F Naqsyahbandi

have been able to achieve the multidimensional category, the student is able to explain ammonia waste management techniques well, by nitrification techniques. Nitrification in the treatment of ammonia waste is one of the right ways to handle ammonia waste in the water (Satria et al., 2019).

Based on the answers and results of student interviews on the question indicator number 1 , it can be known that in general, students are only able to reach the nominal category and a small number can achieve functional categories, while conceptual and multidimensional categories are very low. Soobard \& Rannikmae (2011) reported that only $10 \%$ of students are able to achieve multidimensional categories on socially related issues.

\subsection{Various Categories of Students' Scientific literacy Skills in Explaining Air Environmental Pollution}

Based on data analysis, students' answers are grouped with the same variety of questions so that a percentage of each category will be obtained. the following percentage is presented student distribution answers on question number 2 as shown in Figure 5.

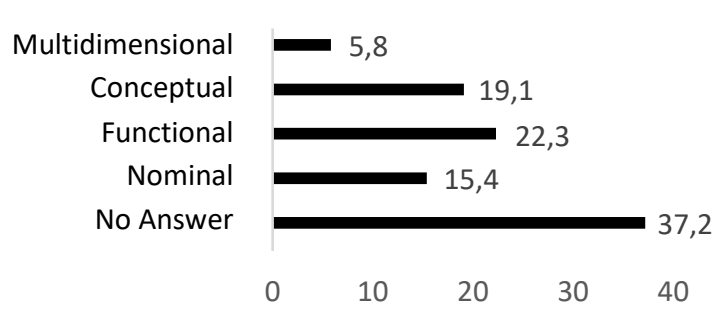

Figure 5. Percentage Distribution of Student Answers on Problem Number 2

Overall, most students were able to achieve nominal, functional and conceptual categories with consecutive percentages of $15.4 \%, 22.3 \%$, $19.3 \%$, and only $5.8 \%$ of students were able to reach the multidimensional category, while as many as $37.2 \%$ of students were unable to answer questions.

Based on the answers and results of student interviews on question 2 indicators, it can be
Exploring Scientific Literacy of Chemistry Education Pre-Service Teachers Through SocioScientific Issues Approach

known that students are only able to achieve in nominal and functional categories, while conceptual and multidimensional categories are still relatively low. This is in line with research conducted by Soobard \& Rannikmae (2011) obtained results that as many as $54 \%$ of learners in answering the test of scientific literacy questions are in the functional category. This is because functional categories are often presented on school exam questions, so students are accustomed to answering questions in this functional category (Bybee, 1997).

\subsection{Various Categories of Student Scientific literacy Ability in Analyzing the Causative Factors and Impacts of Problems (Environmental Impacts, Social, Economic, Health) of the Global Environment}

Overall, the nominal category was achieved with a percentage of $12.2 \%$. The functional category got a fairly high percentage of $33 \%$. The conceptual category was only able to be achieved by $3.2 \%$. The multidimensional category was $11.2 \%$. However, the interesting thing was that as many as $40.4 \%$ of students could not answer the question as shown in Figure 6.

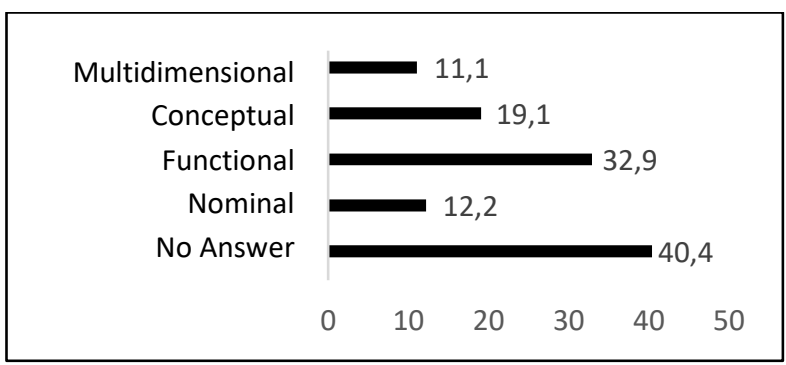

Figure 6. Percentage Distribution of Student Answers on Problem Number 3

The results of the interview showed the student's answer is partially understandable, they learned that CFC is the compound that causes the most depletion of the ozone layer (Manahan, 2010), so the student recommends using equipment that does not contain CFC compounds and using environmentally friendly equipment. Based on the results of analysis of test answers and interview results on question indicator 3 , in general, students' 
J Muhariyansah, A Rahmawati, A Fibonacci \& F Naqsyahbandi

scientific literacy ability is in the functional category (33\%), while for the nominal category the average percentage is $12.2 \%$, conceptual (3.2\%), multidimensional (11.2\%) and $40.4 \%$ of students were unable to give answers to questions.

\subsection{Various Categories of Student Scientific literacy Ability in Explaining Soil Environmental Pollution}

On the accuracy indicators explain the environmental pollution of the soil both examples, sources, types of pollutants, and efforts to control it. Researchers present an article on the phenomenon of forest and land fires. The questions presented about the article include: at point a students are asked to mention at least two impacts resulting from forest and land fires, in point b students are asked to express their opinions on what factors are causing forest and land fires to become an annual disaster for Indonesia. In point $c$ students are asked to explain the process of weather modification technology in the form of artificial rain, and at point $d$ students are asked to provide at least three recommendations and reasons for efforts to control forest and land fires as shown in Figure 7.

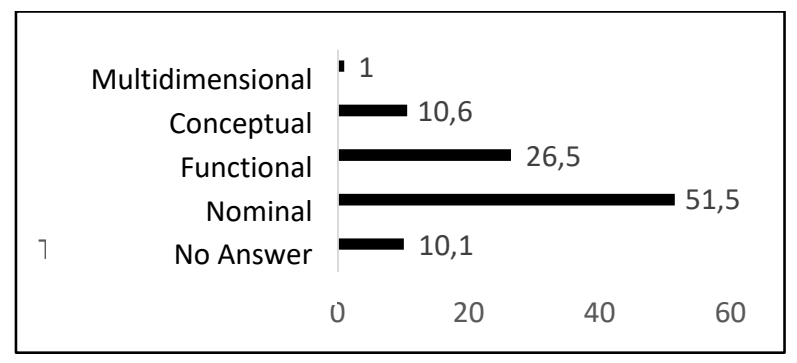

Figure 7. Percentage Distribution of Student Answers on Problem Number 4

In general, in this indicator of question number 4 , the nominal category gets the highest percentage of $51.6 \%$. The multidimensional category gets the lowest percentage of $1 \%$, and $10.3 \%$ of students do not answer questions. In question number 4 point a, Most students are able to answer the question correctly, students are asked to mention at least two impacts due to forest and land fires. Various answers that appear on this question indicate that students have been able
Exploring Scientific Literacy of Chemistry Education Pre-Service Teachers Through SocioScientific Issues Approach

to mention two impacts of forest and land fires. This is in line with the results of the interview, students stated that global warming is closely related to forest and land fires because global warming can lead to irregular climate change, so it is possible that the dry season can be longer, thus triggering forest and land fires.

The results of science literacy tests and student interviews on question 4 indicators show that in general, $51.6 \%$ of students are able to achieve at nominal categories and the lowest percentage in the multidimensional category.

Based on the results of exposure to each question indicator, the average student's scientific literacy ability is in two categories, which are nominal category and functional category, a small part reaches conceptual category while multidimensional category gets the lowest percentage. Soobard \& Rannikmae (2011) said that most students' science literacy skills are in the functional category (54\% of students' answers), because of this category that is usually assessed in school exams, most students answer in this category, because they are accustomed to answering in this way.

\section{Conclusion}

The scientific literacy capability category of chemistry education students is predominantly at two levels, which are the nominal category and functional category. Students' science literacy ability is more in nominal categories with a percentage of $33.2 \%$, in functional categories as much as $24.2 \%$, conceptual categories by $13.7 \%$, a small percentage in multidimensional categories with a percentage of $4.4 \%$. While some students were unable to provide answers on all four test numbers with a percentage of $24.5 \%$. 
J Muhariyansah, A Rahmawati, A Fibonacci \& F Naqsyahbandi

\section{References}

Bybee, R.W. (1997). Toward an understanding of scientific literacy. In: W Graiber \& C. Bolte (Eds). Scientific Literacy: An International symposium 37-68. Kiel, Germany: IPN. Retrieved from https://ci.nii.ac.jp/naid/10021325203/

Cahyono, E. W. (2007a). Pengaruh hujan asam pada biotik dan abiotik. Berita Dirgantara, 8(3), 48-51. Retrieved from http://jurnal.lapan.go.id/index.php/berit a_dirgantara/article/view/718

Cahyono, E. W. (2007b). Urgensi menjaga lapisan ozon bagi penghuni bumi. Berita Dirgantara, 8(2): 38-41. Retrieved from http://jurnal.lapan.go.id/index.php/berit a_dirgantara/article/view/734

Chang, R. (2005). Kimia dasar: konsep-konsep inti. Jakarta: Erlangga, 689-691.

Fives, H., Huebner, W., Birnbaum, A.S., \& Nicolich, M. (2014). Developing a measure of scientific literacy for middle school students. Jurnal Science Education, $98(4): \quad 549 \quad-580$. https://doi.org/10.1002/sce.21115

Holbrook, J., Rannikmae, M. (2009). The meaning of scientific literacy. International Journal of Environmental \& Science Education. 4(3), 275-288. Retrieved from http://files.eric.ed.gov/fulltext/EJ884397 .pdf

Jamaluddin, J., Jufri A. W., Ramdani, A., Azizah, A. (2019). Profil literasi sains dan kemampuan berpikir kritis pendidikan IPA SMP. Jurnal Penelitian dan Pendidikan IPA, 5(1), 120 - 130. https://doi.org/10.29303/jppipa.v5i1.18 5
Exploring Scientific Literacy of Chemistry Education Pre-Service Teachers Through SocioScientific Issues Approach

Leicht, A., Heiss, J., Byun, W. J. (2018). Issues and trends in education for sustainable development. French: UNESCO.

Manahan, S. E. (2010). Water chemistry: green science and technology of nature's most renewable resource. CRC Press.

Moleong, L. J. (2017). Metodologi penelitian kualitatif (Revisi). Bandung: PT Remaja Rosdakarya.

Noviana, M., Julianto, T. (2017). Profil kemampuan literasi sains siswa smp di kota purwokerto ditinjau dari aspek konten, proses, dan konteks sains. Jurnal Sains Sosial dan Humaniora, 1(2), 77 84.

https://doi.org/10.30595/jssh.v1i2.1682

Nuangchalerm, P. (2010). Engaging Students to Perceive Nature of Science through Socioscientific Issues-Based Instruction. Online Submission, 13(1), 34-37. Retrieved from http://files.eric.ed.gov/fulltext/ED50853 1.pdf

Odja, A. H., Payu, C. S. (2014). Analisis kemampuan awal literasi sains siswa pada konsep IPA. Prosiding Seminar Nasional Kimia, Kimia FMIPA Universitas Negeri Surabaya. Retrieved from https://docobook.com/analisiskemampuan-awal-literasi-sains-siswapada-konsep-ipa.html

Pantiwati, Y., \& Husamah. (2014). Analisis kemampuan literasi sains peserta didik SMP Kota Malang. Prosiding Konferensi Ilmiah Tahunan Himpunan Evaluasi Pendidikan Indonesia, Kuta 18-20 September 2014. Retrieved from https://id.scribd.com/document/330595 042/Prosiding-Hepi-2014-Di-Bali 
J Muhariyansah, A Rahmawati, A Fibonacci \& F Naqsyahbandi

Pramurdiarja, U. A. N. (2018, September 30). Viral Kopi Instan Menyala saat Dibakar, Ini Penjelasan Resmi BPOM. detikHealth. https://health.detik.com/beritadetikhealth/d-4235057/viral-kopiinstan-menyala-saat-dibakar-inipenjelasan-resmi-bpom accessed 26 Desember 2019

Prasasti, G. D. (2018, September 30). Heboh Kopi Instan Mudah Terbakar, Begini Penjelasan BPOM. Liputan 6. (2018). https://www.liputan6.com/health/read/ 3655660/heboh-kopi-instan-mudaterbakar-begini-penjelasan-bpom accessed 21 Desember 2019

Prasetyo, H., \& Sutopo, W. (2018). Industri 4.0: Telaah klasifikasi aspek dan arah perkembangan riset. J@ti Undip: Jurnal Teknik Industri, 13(1), 17-26. Retrieved from

https://www.academia.edu/download/5 8028944/INDUSTRI_40_TELAAH_KLASIFI KASI_ASPEK_DAN_ARAH_PERK.pdf

Rodin, R. (2014). Teknologi informasi dan fungsi kepustakawanan. Jurnal $A l$ Maktabah, 13(1), 1-7. Retrieved from http://journal.uinjkt.ac.id/index.php/almaktabah/article/download/1569/1319

Rubin, R. E. (2004). Foundation of Library and Informtion Science 2nd Edition. New York: Neal Schuman Publisher.

Sadler, T. D. (2004). Informal reasoning regarding socio-scientific issues: $A$ critical review of research. Journal of Research in Science Teaching: The Official Journal of the National Association for Research in Science Teaching, 41(1), 513-536. https://doi.org/10.1002/tea.20009

Sadler, T. D. (2011). Situating socio-scientific issues in classrooms as a means of
Exploring Scientific Literacy of Chemistry Education Pre-Service Teachers Through SocioScientific Issues Approach

achieving goals of science education. In Contemporary Trends and Issues in Science Education. Springer, Dordrecht. https://doi.org/10.1007/978-94-0071159-4_1

Sartika, D., Kalsum, U., \& Arsyad A. A. (2018). Analisis kemampuan literasi sains mahasiswa program studi pendidikan fisika Universitas Sulawesi Barat. Jurnal Wahana Pendidikan Fisika, 3(2), 8-12. https://doi.org/10.17509/wapfi.v3i2.137 22

Satria, A. W., Rahmawati, M., \& Prasetya, A. (2019). Pengolahan nitrifikasi limbah amonia dan denitrifikasi limbah fosfat dengan biofilter tercelup. Jurnal Teknologi Lingkungan, 20(2), 243-250. Retrieved from https://scholar.archive.org/work/vazi3qr qj5evdnga3ybc5jtu7i/access/wayback/h ttp://ejurnal.bppt.go.id/index.php/JTL/a rticle/download/3479/pdf

Schleicher, A. (2018). Insights and interpretations. Pisa 2018, 10. Retrieved from

http://www.educationduepuntozero.it/ wp-

content/uploads/2020/01/tabelleOCSEF ierli.pdf

Shwartz, Y., Ben-Zvi, R., \& Hofstein, A. (2006). The use of scientific literacy taxonomy for assessing the development of chemical literacy among high-school students. Chemistry Education Research and Practice, 7(4), 203-225. https://doi.org/ 10.1039/B6RP90011A

Soobard, R., \& Rannikmae, M. (2011). Assessing Student's Level of Scientific Literacy Using Interdisciplinary Scenarios. Science education international, 22(2), 133-144. 
J Muhariyansah, A Rahmawati, A Fibonacci \& F Naqsyahbandi

http://files.eric.ed.gov/fulltext/EJ941672 .pdf

Sugiyono. (2017). Metode Penelitian Kuantitatif, Kualitatif dan R\&D. Bandung: Alfabeta.

Tjandrawinata, R. R. (2016). Industri 4.0: Revolusi industri abad ini dan pengaruhnya pada bidang kesehatan dan bioteknologi. Jakarta: Jurnal Medicinus, 29 (1), 31-39. https://doi.org/10.21009/jtp.v22i1.1528 6

Udompong, L., \& Wongwanich, S. (2014). Diagnosis karakteristik literasi ilmiah siswa sekolah dasar. Procedia-Ilmu Sosial dan Perilaku, 116, 5091-5096. https://doi.org/10.1016/j.sbspro.2014.0 1.1079

Wijayanti, A., Sundari, R. S., \& Agustini, F. (2016). Mengembangkan literasi sains melalui penerapan e-portofolio berbasis
Exploring Scientific Literacy of Chemistry Education Pre-Service Teachers Through SocioScientific Issues Approach

web blog untuk meningkatkan karakter kritis mahasiswa calon guru SD. Media Penelitian Pendidikan: Jurnal Penelitian dalam Bidang Pendidikan dan Pengajaran, 10(1). Retrieved from http://journal.upgris.ac.id/index.php/me diapenelitianpendidikan/article/view/12 52

Zeidler, D. L., \& Nichols, B. H. (2009). Socioscientific issues: Theory and practice. Journal of elementary science education, 21(2), 49. https://doi.org/10.1007/BF03173684

Zeidler, D. L., Sadler, T. D., Applebaum, S., \& Callahan, B. E. (2009). Advancing reflective judgment through socioscientific issues. Journal of Research in Science Teaching: The Official Journal of the National Association for Research in Science Teaching, 46(1), 74-101. https://doi.org/10.1002/tea.20281 